\title{
Collaborative Inquiry For 4C Skills
}

\author{
Diana Hani Sipayung \\ Post graduated of Physics Education \\ Medan State University \\ Medan, Indonesia \\ hani1122diana@gmail.com
}

Rahmatsyah

Lecturer Pascasarjana Medan State University

Medan, Indonesia

\author{
Ridwan Abdullah Sani \\ Lecturer Pascasarjana Medan State University \\ Medan, Indonesia \\ Henry Bunawan \\ Lecturer Pascasarjana Medan State University \\ Medan, Indonesia
}

\begin{abstract}
This study aims to determine the effect of collaborative inquiry learning model in improving the skills of 4C (Collaboration, Communication, Critical Thinking, and Creativity) students compared with conventional learning. The study population was all students of tenth grade seven high school in Medan for second semester of the academic year 2017/2018. The sample in this study was taken by cluster random class, the experimental class using inquiry and collaborative learning model class control using conventional learning. The variables in the study consisted of $4 \mathrm{C}$ skills as dependent variables and collaborative inquiry models as independent variables. Data were analyzed using t-test. The results showed that the collaborative inquiry learning model is better than the conventional study to improve students' skills for learning physics $4 \mathrm{C}$ on the material impulse, momentum and collisions in high school. Student achievement due to the learning process of collaborative inquiry can train students to learn reorganize knowledge through reflection and analysis together, reconstructed through collaborative action, and build knowledge together through their experience to learn and use a variety of resources and implement all the strategies as well as their skills in actions during the course of the investigation.
\end{abstract}

Keywords: collaborative inquiry, collaboration, communication, critical thinking, creativity

\section{PRELIMINARY}

Education 21st century should immediately move from traditional learning to modern education so students have the knowledge, learning and innovation skills, using technology to find information, and survive using skills for life skills [17;16;1]. The Ministry of Education and Culture of the Republic of Indonesia developed the 2013 curriculum by adopting three concepts of 21 st century education namely 21 st Century Skills, scientific approach, authentic assessment [18]. The 21st-century learning reflects four learning objectives (4C) which refers to the part of learning to do, namely Critical Thinking, Creativity, Communication, and Collaboration [40;33]. According to [36], there are three important study subject in the context of 21st-century skills, namely life and career skills, learning and innovation skills, and information media and technology skills. On the subject of learning and innovation skills or can be called learning and innovation skills described as critical thinking skills, communication and collaboration, creativity and innovation, which are taught in every context of core study fields and learning themes of the twenty-first century in this study physics [42].
Physics can basically be viewed as a process and product, so learning physics should not override the concept of the discovery process. Physics as the process is not effective if only focused on the mastery of the material, but should emphasize the acquisition of skills [37;29]. Physics as the product includes a set of knowledge consists of facts, concepts, and principles of physics [5]. Physics learning process should emphasize the provision of direct experience so as to develop the competence of learners so that learners can better understand the various natural phenomena around scientifically [23].

Problems encountered in the teaching of physics in the 21 st century is generally not limited to the ability to master the concept of physics, but also requires students to develop the ability to think critically that allows students to analyze the results of his thinking in making choices and draw conclusions with intelligent $[23 ; 29 ; 5]$. The ability to think critically is a reflective and reasoned way of thinking that is focused on decision-making to solve the problem [11].

Critical thinking is important in the twenty-first-century learning because the skills necessary to find sources of quality information, an objective in assessing that can compare detailed evidence in formulating and responsible in making decisions. Critical thinking involves accessing, analyzing and synthesizing information, and can be taught, practiced and mastered [11]. Critical thinking skills also refer to other skills such as communication, information literacy and the ability to examine, analyze, interpret and evaluate evidence $[36 ; 12])$. Inquiry is a learning that can train students' thinking skills to solve the problem that is skilled, skilled critical thinking, creative thinking and innovative skilled $[9 ; 37 ; 23 ; 29 ; 15 ; 12]$. Indicators of critical thinking skills by Watson and Glaser is the inference, assumption, deduction, interpretation, and evaluation [45].

Finding a solution to the complex problems of the 21st century requires a range of skills associated with critical thinking, innovation, and creativity [36;9]. Creativity and innovation are indispensable for this thought process can produce innovative solutions from a problem and produce the products as a result of new thinking. Learning skills and learning innovations facilitate mastery of other skills such as the ability to recognize perspectives, communicate ideas, take a creative and relevant action to solve complex problems [1]. Creativity is defined as a way of thinking which uses various techniques of making new ideas and useful concepts, outlines, refine, analyze, and evaluate the 
original idea for maximum results [31]. The future of mankind depends on the ability to rearrange and put creativity and innovation at the forefront of the current educational system [36]. The statement was in line with [8] which emphasizes knowledge creativity, conceptual work where there is no wrong answer or many answers correct, requires the creation of knowledge to collaborate, identify and select the best answer. According to Torrance indicator smoothness creativity (fluency), flexibility (flexibility), authenticity (originality), detailing / decomposition (elaboration) [43]. The future of mankind depends on the ability to rearrange and put creativity and innovation at the forefront of the current educational system [36]. The statement was in line with [8] which emphasizes knowledge creativity, conceptual work where there is no wrong answer or many answers correct, requires the creation of knowledge to collaborate, identify and select the best answer. According to Torrance indicator smoothness creativity (fluency), flexibility (flexibility), authenticity (originality), detailing / decomposition (elaboration) [43]. The future of mankind depends on the ability to rearrange and put creativity and innovation at the forefront of the current educational system [36]. The statement was in line with [8] which emphasizes knowledge creativity, conceptual work where there is no wrong answer or many answers correct, requires the creation of knowledge to collaborate, identify and select the best answer. According to Torrance indicator smoothness creativity (fluency), flexibility (flexibility), authenticity (originality), detailing / decomposition (elaboration) [43]. conceptual work where there is no wrong answer or many answers correct requires the creation of knowledge to collaborate, identify and select the best answer. According to Torrance indicator smoothness creativity (fluency), flexibility (flexibility), authenticity (originality), detailing / decomposition (elaboration). conceptual work where there is no wrong answer or many answers correct requires the creation of knowledge to collaborate, identify and select the best answer. According to Torrance indicator smoothness creativity (fluency), flexibility (flexibility), authenticity (originality), detailing / decomposition (elaboration) [43].

Essential Skills are also needed by the human resources in the 21 st century is the communication and collaboration skills. Communication and collaboration at the same time strongly reflect the adult world. In this context, the skills of effective communication and collaboration can help avoid misunderstandings and miscommunication. Collaboration is an attempt to demonstrate the ability to work effectively and respectfully with diverse teams to achieve common goals with shared responsibility [31]. Collaboration and teamwork in the twenty-first century will be developed in schools, between schools, and between experience outside of school and out of school $(30 ; 21 ; 26]$. The indicator for the skills of collaboration among students' ability to work together and the leadership of the group, to adapt in a variety of roles and responsibilities, work productively with others, put empathy in place, respect for different perspectives.

Strong communication skills including the ability to express thoughts clearly and persuasively both orally and in writing, articulate opinions, communicate instructions are coherent and motivating others through speech $[40 ; 26 ; 36)$. Communication can be defined in various ways, but the P21 defines the communication skills to say with clear, articulate thoughts and ideas as well as the effective use of communication capabilities [31]. Communications became one of the important skills that must be possessed by students. Therefore, a scientific approach to the curriculum in 2013 in one of its core activities is to communicate. Competence to communicate can be observed include,1) communication in an open, friendly and polite,

$4 \mathrm{C}$ is a skill that must be mastered competence of the nation to be competitive in the 21st-century life skills Achievement can be done by learning innovation tailored to the problem or project-based learning, encourage cooperation, communication training, empowering metacognition, designing relevant learning with the real world, and student-centered. [47; 35; 39] Skills students to communicate, collaborate, think critically and creatively in Indonesia is still less competent and they must continue to be improved, especially for science subjects $[47 ; 35 ; 38 ; 29$; 46].

The success of the learning process of physics in schools currently only be seen from the results of student learning is a product that can be measured by learning activities in accordance with the graduation exam. So that students in physics can learn quite limited to preparing rote formulas for test items and be able to answer the exam questions in the mathematical aspects of the course is not to train students' competencies needed in the 21st-century learning. The learning activities that take place in class still emphasizes the role of teachers in a leading role in the learning process. Teachers also still give priority to the thoroughness of the material and lack of completeness optimize student learning. Students only receive the information provided by the teacher, so that active participation in learning is less visible. In addition, students are also still not trained to communicate actively, especially when collaborating with good friends in a group and between groups. The above problem results in student learning physics by only focusing on activities memorizing mathematical equations, not to practice critical thinking skills to analyze a problem and find a creative solution as a result of the problem solving [37].

The results of questionnaire data from observations in Seven state senior high school in Medan obtained that the collaboration capabilities of students still need to be developed for $65 \%$ of students prefer to listen than to speak or ask questions, $70 \%$ of students can not provide arguments and solutions when discussing, $60 \%$ of students can not understand the material physics taught by group learning. Likewise, where the communication capability, $60 \%$ of students are not able to declare the results of the settlement of the problems of physics into mathematical calculations either in writing, using pictures or graphics, $63 \%$ of students can not disclose the results of an analysis of an observation with communicative language.

Based on these descriptions, efforts should be made to overcome the above problems is by developing a model of effective learning, which can attract the attention of students, motivating students, involving students actively, and to train the student's ability both critical thinking, creative thinking, collaboration, and communicate. One of the alternatives that can be used to overcome this difficulty is to create a learning environment that aims to guide students in acquiring knowledge that is the investigation [23]. One way that can be used to critical the skills of communication, collaboration, critical thinking and creative 
in applying the model of collaborative inquiry learning [20;25].

The collaborative model of inquiry is a process of learning in which participants gather to examine their own learning practices in a systematic and careful use of research techniques. The group worked together to narrow the questions, collect and analyze the evidence, determine the action steps, and ultimately share their findings and recommendations. Results of collaborative inquiry are prudent measures which aim to improve the practice of evidence-based on the complex examination (Donohoo, 2011). Stoll describes the investigation as a means whereby collaborative learning community "reorganize knowledge through reflection and analysis together, reconstructed through collaborative action, and build knowledge together through collective learning from their experiences to learn strategies in finding solutions to the problem, evaluated by using various resources and implement all the strategies as well as their skills into action during the investigation process. Collaborative inquiry is also expected to add boldness in communicating both ask and express opinions for their guidance that will lead students to interact socially with a group [25].

Collaborative inquiry is a teaching design that are proven to provide a significant impact on student collaboration and communication capabilities (Lawrie et al, 2014; Brailas et al, 2017; Kasimatis et al, 2014). In addition to the ability of collaboration and communication, model of collaborative inquiry was also to increase the critical thinking skills and creativity of the students to help students summarize the questions that arise from the problems faced, looking for a variety of information from many sources, and find a solution as a result of innovation creative thinking $[14 ; 20 ; 25]$. The inquiry Collaborative learning phase is that discussing the issue, gathering evidence, analyzing evidence, and celebrate and share [10].

\section{RESEARCH METHODOLOGY}

This is a quasi-experimental study with the population of all students of class $\mathrm{X}$ of SMAN 7 Medan and sample determined by random classroom techniques (cluster random class) as much as two classes: one class used as the experimental class using inquiry and collaborative learning model used other class control class using conventional teaching models. This study design is a two-group pretestposttest. This type of research is a quasi-experimental (quasiexperimental) because the class is used for treatment (treatment) is a class that has been formed previously. This variable involves five kinds of research variables are four dependent variable and one independent variable. The dependent variable is the $4 \mathrm{C}$ skills of students in physics TP second semester 2017/2018.

The instrument used in this study as many as four types of instruments on the material impulse, momentum and collisions, the instrument skills of collaboration refers to indicators Roekel (2011), then the instrument communication skills using indicator according Sani [33], then the instruments and indicators of critical thinking skills by Watson and Glaser, and creative thinking skills instrument indicator according to Torrance. The data obtained were analyzed in advance to test the hypothesis, after first tested for normality using the test One sample Shapiro-Wilk and homogeneity of data to determine both samples come from a homogenous population, with distributes data into the table one way ANOVA. This process will produce output Test of homogeneity of Variances. All of this research test wear SPSS 17.0 program, Hypothesis testing is done by using tat significance level of 0.05 .

\section{RESULTS AND DISCUSSION}

Collaborative inquiry learning model and conventional learning essentially equally provide opportunities for students to practice a wide range of abilities and skills as a result of learning. The results obtained in this study indicate there are differences in the experimental class 4C skills using collaborative inquiry learning model and grade control using conventional learning. Learning the real science has long been ineffective if it continues to be taught in a conventional manner either by a lecture or discussion because it has been the shifting needs of students as a form of learning outcomes [25]

Increased 4C skills students use collaborative inquiry learning model is better because this model has several advantages, namely collaborative investigation gives freedom to the teacher to determine the process and themes of learning so as to empower students and to guide students desire to stay involved during the collaborative inquiry. The students then determine what they want to do to resolve the problem, or what they would do differently based on each group's discussion related to the theme. Furthermore, students can collaborate and communicate at the same time, so that among the students begin to have confidence in answering questions through observation, express opinions, ideas or ideas.

The inquiry collaborative learning makes students more active during learning both in expressing their questions, opinions, suggestions and creative ideas regarding solutions to a given problem [24]. Teachers can train students' ability of creativity in terms of designing a solution for the problem have more efficient performance in terms of use of time. Collaborative learning model also has the potential to reduce the gap between students who have high academic skills with students of lower academic ability. Collaborative learning can train students to learn to solve problems, think logically, devised an experiment in collaboration, and this can be seen when students work together in groups, put forward a hypothesis and when the student asked the teacher, and when students express opinions or express what can students in the learning process $[20 ; 8]$. Skills of students before and after treatment in experimental and control classes can be seen in Figure 1, Figure 2 and Figure 3.

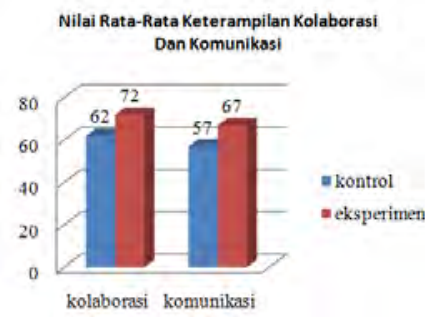

Fig 1. Collaboration and Communication Students after treatment 


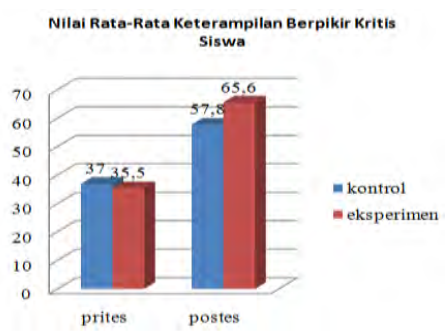

Fig 2. Critical Thinking Students Before and After Treatment

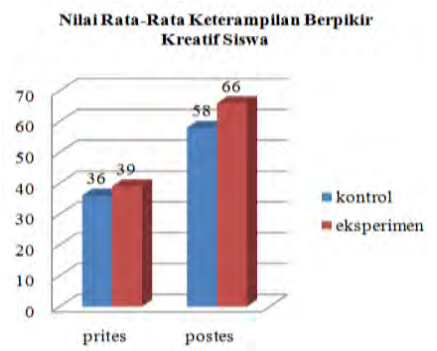

Fig 3. Creative Thinking Students Before and After Treatment

\section{A. Collaborative Learning Collaborative Inquiry Skills Against Students}

In Figure 1 we can see that the average value skills student collaboration after treatment in class experiments higher at 72 than in the control class is 62 , this is because the learning model of collaborative inquiry offers the potential among students to support each other in constructing knowledge and understanding together aiming to create a learning environment that encourages student involvement in improving communication and collaboration skills [41; 36; 2]. Implement collaborative group work is to achieve positive interdependence among students in the group. Collaborative learning can improve teamwork where learning activities are divided among the members of the group but the group as a whole is responsible for the outcome [25]

The learning collaborative inquiry allows students to have a sense of enthusiasm to experiment, learn on their own with the group, shared learning from mistakes that might do the group, collaborate to identify and find the best option, to increase participation and interaction students to collaborate in small groups [8]. The impact of conventional learning are more students relying upon the teacher proved when given the matter a little different with examples of questions the students will fully need direction from the teacher to finish and look more members of the group are passive rather than active when the discussion took place, causing the skills of collaboration and communication students in the control class is low. We recommend the traditional learning methods which still dominates the lecture method should be reduced to a minimum and be replaced with a more innovative learning activity $[8 ; 25]$.

\section{B. Collaborative Inquiry Learning Communication Skills Of Students}

communication skills both orally and in writing is a skill required and must be owned by the students in the modern era as one of the most important skills [36]. Based on the graph one can see that the communication skills of students in the experimental class and control class after being given the treatment showed an average value of 67 to 57 for the experimental class and control class. The conclusion that can be drawn is the communication skills of students taught in collaborative inquiry learning model is higher than the communication skills of students taught by conventional learning models. The collaborative inquiry revealed that the students can develop the ability to answer questions through observation, then communicating [14]. Collaborative learning activity offers the potential for mutual support construction of knowledge and mutual understanding among the students. Collaborative inquiry learning outcomes aim to create a learning environment that encourages student involvement and enhance students' communication skills. With the communication skills of the students will be a good science communicator to communicate scientific results, inform or argue for various purposes by various methods [25].

\section{Learning Collaborative Inquiry Against Students Critical Thinking Skills}

The average value obtained by the student's critical thinking skills in the experimental class before being given treatment was 35.5 while the control class is 37 . The data in Figure 4.2 shows that an increase in the average value of students' critical thinking skills after treatment that becomes 65.6 in the experimental group and 57.8 in the control class. The critical thinking skills of students in the experimental class can be increased with applied learning model for a collaborative inquiry-based learning experience with constructivist theory [8].

Collaborative Inquiry Learning effective for some science subjects are designed to enhance the students' understanding of complex concepts more efficiently than traditional learning [24]. Kasimatis presented research results found a positive effect Collaborative Inquiry in increase problem-solving abilities, motivating the students and the students' critical thinking [20]. Collaborative inquiry is a form of learning that is innovative to practice critical thinking skills of students, information processing in depth, balance of knowledge and give priority to the development of skills of students in accordance with the teaching of the 21 st century that is critical, creative, collaborate in identifying and creating the best choice, and be able to solve the problem, where students are guided to the discovery of the theoretical foundations of a way to collaborate with a small group [10; 41].

\section{Learning Collaborative Inquiry Against Students Creative Thinking Skills}

The average value of the student's creative thinking skills in the experimental class before being given treatment the average values obtained are 39 while the control class is 35.8 . After the second class are given a different treatment, which is a class experiment with collaborative inquiry learning model and grade control using conventional teaching method of discussion, the obtained average value of creative thinking skills of students in the experimental class is 66 and in the control group was 58 per drawing 4.2. Kasimatis research results show that there are positive effects of collaborative inquiry to the creative thinking of students [20]. Correspondingly, Other research results also noted that collaborative inquiry is an effective way to train students to be creative in a way that might reflect students' mistakes do 
or conclude into an advantage of the learning process for soon formulate some alternative answers [8].

Experimental class learning model collaborative inquiry makes students more active due to such teams work together to narrow the questions, collect and analyze the evidence, determine the steps, and share their findings and recommendations. Results of collaborative inquiry produces a wise move aimed at improving practices based on thorough examination of evidence regarding concepts in the material momentum, impulse and collisions where the teacher also helps students engaged and more involved in analyzing and finding the best solution or provide an alternative solution [10; 41], Learning constructive individually or itself a learning activity that is found to be less effective in learning and problem-solving task when compared with activity more interactive learning such as responding to questions, explain to others, and discuss with your partner to produce an explanation collaborative [3].

The learning model of collaborative inquiry was designed with the aim to help students develop the curiosity of students in learning the concepts and principles of physics as well as helping students to reconstruct the concept of physics obtained from exploratory activities directly through a process of critical thinking and creative [20; 24, 2017; 44].

\section{CONCLUSIONS \& RECOMMENDATIONS}

The conclusion of this study showed that the skills $4 \mathrm{C}$ (Collaboration, Communication, Critical Thinking and Creativity) students that learned using learning collaborative inquiry better than using conventional methods. For further research should be able to use a variety of instructional media to convey the problems that need to understand the students, so that events can be seen as more real and not abstract. Moreover, it can make students more interested to start learning to follow.

\section{References}

[1] Acedo, C and Hughes. C. 2014. Principles For Learning And competences In The 21st-Century Curriculum. Springer Journal, 44: 503-525

[2] Adams, P. 2016. Learning Preparing Teachers The Role Of Collaborative Inquiry. Canadian Journal of Action Research, 17 (1), 20-35

[3] Andiliou. A., Murphy, PK 2014. Creative Solutions and Their Evaluation Comparing the Effects Of Explanation and Argumentation Tasks on Student Reflections. Frontline Learning Research, 5 (1), 92-114

[4]Arends. Learning 2008. To Teach.Yogyakarta: Student Library.

[5 [Bahtiar., Wasis., Rahayu, SR 2016. A Guided Inquiry-Based Approach Physics Students Practice Model To Improve Critical Thinking Skill. International Conference On Education (IECO). 1 (1): 96-108

[6] Bailin. S. 2002. Critical thinking and science education. Science \& Education, 11 (4), 361-375.

[7] Birgili, B. 2015. Creative and Critical Thinking Skills in Problem Based Learning Environments. Journal of Gifted Education and Creativity, 2 (2), 71-80

[8] Brailas. A., Avani. BC, Gkini. C., Deilogkou. MA, Koskinas. K. 2017. Experiential Learning in Action: A Collaborative Inquiry. Journal The Qualitative Report, 22 (1): 2-20.

[9]Deta. UA, Suparmi., Widha. S. 2013. Effects of Guided Inquiry Method And Project, Creativity, And Science Process Skills Against Student Achievement. Indonesian Journal of Physics Education, 9: 28-34

[10] Donohoo. J. 2011. Collaborative Inquiry A Facilitator's Guide. Canada: MISA
[11] Ennis. RH 1986. Goals for a Critical Thinking Curriculum ,. In AL Costa (Ed), Developing Minds. Virginia: Association for Supervision and Curriculum Development.

[12] Fisher. A. 2008. Critical Thinking: An Introduction, Translation by Benjamin Hadinata. Jakarta: Erland.

[13] Fuad. NM, Zubaidah. S., Mahanal. S., Suarsini. 2017 E. Junior High Schools Improving Critical Thinking Skills Test Based on Three Different Models Of Learning. International Journal of Instruction, 10 (1): 101-116

[14] Gibson. T. 2017. An Examination Of How Middle School Science Teachers Conduct Collaborative Inquiry And Reflection About Students' Conceptual Understanding. Contemporary Issues in Education Research, 10 (2): 169-178

[15] Gora, W and Sunarto. PAKEMATIK 2009. Innovative ICT-Based Learning Strategy. Jakarta: Elexmedia Komputindo

[16] Henriksen. D., Mishra. P., Fisser. P. 2016. Infusing Creativity and Technology in 21st Century Education: A Systemic View for Change. Educational Technology \& Society, 19 (3): 27-37.

[17] Higgins. S. 2014. Critical thinking for 21st-century education: A cybertooth curriculum ?. Springer Journal, 44: 559-574

[18] Hosnan. 2014 a scientific approach and the 21st Century Learning Contextual Bogor: Ghalia Indonesia.

[19] Junaidi. M., Sunarno. W., Search. 2014. Learning Physics Through Guided Inquiry Approach Experimental Methods and Projects Seen From Student Activities and Scientific Attitude. Inquiry Journal, 3 (3): 41-52

[20] Kasimatis. A., Petropoulou. O., Retalis. S., Dimopoulos. I., Psaromiligkos. I., Karaggelis. K. 2014. Using Moodle And EAssessment Methods A Collaborative Inquiry Learning During Scenario. Pedagogical and Technological Education Journal, 01: 1-7.

[21] Keane. T., Keane. WF, Blicblau. AS 2014. Beyond traditional literacy: Learning and transformative practices using ICT. Springer Science Journal, 1: 1-13

[22] Ku, KY, 2009. Assessing students' critical thinking performance: urging for measurements using multi-response format. Thinking Skills and Creativity, (4), 70-76.

[23] Kurniawati. ID, Wartono Diantoro. M., 2014.Effect of Guided Inquiry Learning Integration of Peer Instruction to Control Concepts and Critical Thinking Skills Students, Journal of Physical Education Indonesia. 10: 36-46.

[24] Last., Sajidan and Prayitno. BA 2017. Development of Collaborative Inquiry Learning Model-Based Local Potential And Implementation On Plant Material Moss and Spikes. JOURNAL inquiry, 6 (1): 1-16

[25]Lawrie. GA, Matthews. KE, Bailey. C., Kavanagh. LJ, Gahan. LR, Weaver. GC, Adams. P., Long. PD 2014. Technology Supported Facilitation And Assessment Of Small Group Collaborative Inquiry Learning In Large First-Year Classes. Journal of Learning Design, 7 (2): $1-16$

[26] Mishra. P and Mehta. R. 2017. Educators What We Get Wrong About 21st-Century Learning: Results of a Survey. Journal of Digital Learning in Teacher Education, 33 (1): 6-19.

[27]Munandar and Utami. 2009. Developing Talent and Creativity School Children, The Tips For Teachers And Parents. Jakarta: PT. Gramedia Widiasarana Indonesia.

[28]Paul, RW, \& Elder, L. 2013. Critical Thinking: Intellectual Standards Essential to Reasoning Well Within Every Domain of Human Thought. Journal of Developmental Education, 37 (1), 32-36.

[29] Pratiwi. T. R and Muslims. 2016. Learning Ipa Integrated mode To Improve Critical Thinking Skills Junior High School Students. Indonesian Journal of Physics Education, 12 (1): 54-64

[30] Quieng. MC, Lim PP, Lucas. MRD-based 21st Century 2015. Soft Skills: Spotlight on Non-Cognitive Skills in a Cognitive-laden Dentistry Program. European Journal of Contemporary Education, 11 (1): 72-81

[31]Roekel, DV 2011. Preparing Students For a 21st Century Global Society An Educator's Guide to the "Four Cs". National Education Association: Canada

[32] Sam, C., Tavares, NJ, Donna, C., Ho Shun, Y., Ken, C., Felix, S., Mona, W. 2012. Upper Primary Students Developing 21st Century Skills. Hongkong: Quality Education Fund

[33] Sani, RA 2014. Scientific Learning To 2013. Earth Literacy Curriculum Implementation: Jakarta

[34] Sani, RA 2016. Authentic Assessment. Earth Literacy: Jakarta

[35] Saputri, air conditioning, Sajidan., Rinanto. Y. 2017. Identification of Critical Thinking Skills Students in Learning Biology Using Window 
Shopping. Proceedings of the National Seminar on Science Education (SNPs), 1 (1): 131-135

[36]Scott, CL 2015. The Futures Of Learning 2: What Kind Of Learning For The 21st Century ?. Education Research And Foresight UNESCO Working Papers, 1-14

[37] Simbolon, DH, Sahyar. 2015. Effect of Guided Inquiry Learning ModelBased Virtual Laboratory Experiments Against Rill And Physics Student Learning Outcomes. Journal of Education and Culture, 21 (3): 299-315

[38]Siswanto., Kaniawati, I., Suhandi, A. 2014. Application of Learning Model Generation Arguments Using Scientific Methods To Improve Cognitive Ability and Skills Students Argue. Indonesian Journal of Physics Education, 10 (2): 104-116.

[39]Susilawati., Ristanto, S., Khoiri, N. 2015. Learning Real Physics Laboratory and Task Mandiri Siswa Smk In Accordance With 21st Century Skills Indonesian Journal of Physical Education, 11 (1): 73-83

[40]Susilo. 2015. Curriculum of EFL Teacher Education and Indonesian Qualification Framework: A Blip of the Future Direction. The dynamics of the journal Science, 15 (1): 11-24

[41] Stoll, L. 2010. Connecting Learning Communities: Building Capacity For Systematic Change, In A. Hargreaves, A. Lieberman, M. Fullan, \& D. Hopkins (Eds.). Second international handbook of educational change. Dordrecht, Springer: International Handbook of Education, 23 (1): 469-484
[42] Tan, C., Chua, C. S. K., Goh, O. 2015. Rethinking the Framework for 21st-Century Education: Toward a Communitarian Conception. Journal Routledge Taylor \& Francis Group, 79: 307-320.

[43]Torrance, EP 1990. Torrance tests of creative thinking verbal forms A and B: Manual for scoring and interpreting results. Benseville, IL: Scholastic Testing Service.

[44] Williams. MC 2015. Exploring the Benefits of a Collaborative Inquiry Team in Education (CITE) Initiative to Develop a Research Community and Enhance Student Engagement. Brock Education Journal, 25 (1): 5572

[45]Watson, GB, \& Glaser, 1980 EM Watson-Glaser Critical Thinking manual. San Antonio, TX: The Psychological Corporation, Hartcourt Brace.

[46]Yuliati, Y. 2017. Science Literacy in Learning Ipa. Pendas Horizon Journal, 3 (2): 21-28.

[47] Zubaidah, 2016 S. 21st Century Skills: Skills Taught Through Learning. State University of Malang Journal, 1 (1): 1-17 